\title{
Methicillin resistant Staphylococcus aureus in Ethiopia: a meta-analysis
}

\author{
Setegn Eshetie ${ }^{1 *}$, Fentahun Tarekegn ${ }^{2}$, Feleke Moges ${ }^{1}$, Anteneh Amsalu ${ }^{1}$, Wubet Birhan ${ }^{1}$ and Kahsay Huruy ${ }^{1}$
}

\begin{abstract}
Background: The burden of methicillin resistant Staphylococcus aureus is a major public health concern worldwide; however the overall epidemiology of multidrug resistant strains is neither coordinated nor harmonized, particularly in developing countries including Ethiopia. Therefore, the aim of this meta-analysis was to assess the burden of methicillin resistant Staphylococcos aureus and its antibiotic resistance pattern in Ethiopia at large.

Methods: PubMed, Google Scholar, and lancet databases were searched and a total of 20 studies have been selected for meta-analysis. Six authors have independently extracts data on the prevalence of methicillin resistant Staphylococcus aureus among clinical isolates of Staphylococcus aureus. Statistical analysis was achieved by using Open meta-analyst (version 3.13) and Comprehensive meta-analysis (version 3.3) softwares. The overall prevalence of methicillin resistant Staphylococcus aureus and its antibiotic resistance pattern were pooled by using the forest plot, table and figure with $95 \% \mathrm{Cl}$.

Results: The pooled prevalence of methicillin resistant Staphylococcus aureus was 32.5\% (95\% Cl, 24.1 to 40.9\%). Moreover, methicillin resistant Staphylococcus aureus strains were found to be highly resistant to penicillin, ampicillin, erythromycin, and amoxicillin, with a pooled resistance ratio of 99.1, 98.1, 97.2 and $97.1 \%$, respectively. On the other hand, comparably low levels of resistance ratio were noted to vancomycin, 5.3\%.

Conclusion: The overall burden of methicillin resistant Staphylococcus aureus is considerably high, besides these strains showed extreme resistance to penicillin, ampicillin, erythromycin and amoxicillin. In principle, appropriate use of antibiotics, applying safety precautions are the key to reduce the spread of multidrug resistant strains, methicillin resistant Staphylococcus aureus in particular.
\end{abstract}

Keywords: Methicillin resistant Staphylococcus aureus, Meta-analysis, Systematic review, Ethiopia

\section{Background}

Staphylococcus aureus is one of a versatile pathogen and the main cause of hospital and community acquired infections, the disease ranging from mild skin infection to life-threatening sepsis [1]. Moreover, S. aureus evolves various drug resistance mechanisms, subsequently results difficulty in the management of infections. Resistance is, of course, the evolutionary consequence of the deployment of selective pressure; therefore, it has been well indicated among pathogenic bacteria including $S$. aureus. Following discovery of penicillin 1940s, penicillinase producing $S$. aureus were demonstrated, leading to development of semi-synthetic penicillins such as methicillin,

\footnotetext{
*Correspondence: wolet03.2004@gmail.com

'Department of Medical Microbiology, College of Medicine and Health

Sciences, University of Gondar, P. O. Box: 196, Gondar, Ethiopia

Full list of author information is available at the end of the article
}

which was the most effective antibiotics for penicillin resistant strains $[2,3]$. Despite the fact that, the antibiotic was no longer effective due to the emergence of methicillin resistant S.aureus (MRSA), which has become a grave public health concern because of higher mortality and morbidity due to invasive systemic infections $[4,5]$.

Methicillin resistant largely attributed by due to acquisition of mecA gene, found in the Staphylococcal cassette chromosome mec (SCCmec) that codes unique penicillin binding protein (PBP2a), which has low affinity to methicillin and other beta-lactam antibiotics. Recently, new resistance gene so called mecC as also identified from MRSA isolates from clinical specimens. Methicillin resistant Staphylococcus aureus has mostly considered a nasocomial pathogen since it is increasingly associated with prior exposure to health care facility. Surprisingly, new 
MRSA variants were also reported from community settings lacking traditional risk factors. Since then, it is well understood that there are two distinct types of MRSA were recognized; hospital-acquired and communityacquired MRSA. Hospital-acquired MRSA strains are resistant not only to beta-lactam agents but also to other types of antibiotics, and mostly associated with type I, II and III SCCmec. However, community-acquired MRSA strains are usually resistant to beta-lactams but susceptible to other antimicrobials, and linked mostly with the SCCmec type IV and V [6, 7].

According to the evidences, the burden of MRSA has been increasing at an alarming pace throughout the world with showing considerable variation in prevalence according of geographical area or region $[8,9]$. Understanding the overall epidemiology of MRSA at country level is so substantial to underpin effective prevention and control strategies. Therefore, the aim of this meta-analysis was to summarize available data and to determine pooled prevalence MRSA and its antibiotic resistance in Ethiopia by conducting a systematic review and meta-analysis.

\section{Methods}

\section{Study selection}

A literature search was conducted in the PubMed, Lancet and Google Scholar databases and articles potentially relevant to our study were identified. The search was performed by six authors (SE, FT, AA, FM, WB and $\mathrm{KH}$ ) independently, by using the following terms as keywords (and combinations thereof) "Staphylococcus aureus", "S. aureus", "antibiotic resistance profile of $S$. aureus", prevalence", "methicillin resistant S. aureus", "MRSA", and "Ethiopia". Among the citations extracted, abstracts were reviewed in an attempt to retrieve the clinical studies on MRSA colonization. Articles that were relevant, by title and abstract, were accessed in full text to determine those that provided sufficient information to be included in our meta-analysis. Finally, the references cited by each eligible study were scrutinized to identify additional articles.

\section{Inclusion and exclusion criteria}

Studies were included in our meta-analysis, if they reported extractable data on the prevalence of MRSA in Ethiopian hospitals or research centers and only English language papers were imposed. On the other hand, studies that did not report on a study of MRSA and failed to comply with Ethiopian setting were excluded from the study.

\section{Outcome of interest}

The major outcome of interest was the prevalence of MRSA among total S. aureus clinical isolates. The prevalence was calculated by dividing the numbers of MRSA isolates of the total number of clinically isolated $S$. aureus. As secondary outcomes of interest, we have also calculated the pooled resistance pattern of MRSA isolates to specific antibiotics.

\section{Data extraction}

Data from eligible studies were extracted independently by authors and summarized into a spreadsheet. Discrepancies were resolved by consensus. For each of the included studies, the following information was extracted; name of regions, study area/city, study names, year of the study, study design, types of specimens, numbers of patients/study participants, total numbers of $S$. aureus, proportion of MRSA and references.

\section{Quality control}

The quality of eligible studies was checked independently by three authors (SE, AA, \& WB) using a set of predetermined criteria such as research design, quality of paper, and employed methods for MRSA isolation.

\section{Data analysis}

A random effects model was used to determine pooled prevalence and the 95\% confidence interval (CI), by employing the approach of DerSimonian and Laird [10]. Besides, Freeman Tukey arcsine methodology was also used to address stabilizing variances [11]. The standard approach of inverse variance method to calculate pooled prevalences does not work well in meta-analysis of single arm study because, for studies with small or large prevalence, the inverse variance method causes the variance becomes small and the calculated CI may outside the range. Therefore, Freeman Tukey arcsine methodology is recommended to correct both variances instability and CIs [12]. We assessed the heterogeneity of study results by the use of $\mathrm{I}^{2}$ test. Significant heterogeneity was considered for $P<0.10$ and $\mathrm{I}^{2}>50 \%[10,13]$. The small study bias was measured by Begg's funnel plot [14]. The overall prevalence of MRSA was pooled by the forest plot with 95\% CI, and regional prevalence was summarized by using figure. In secondary analysis, we have calculated the resistance pattern of MRSA to specific antibiotics, and was presented by using table. Statistical analysis was performed by the use of the Open Meta Analyst (version 3.13) and Comprehensive Meta Analysis (version 3.1).

\section{Results}

Through electronic database search, we have found a total of 423 abstracts, among these studies, 321 were disregarded after reviewing their titles, 18 were found to be duplicates, and 64 were excluded because the abstracts or full text information did not directly related to the topic of interest i.e. prevalence of MRSA. Finally, 20 articles fulfilled our eligibility criteria and were subjected to meta-analysis [15-34] (Fig. 1). 


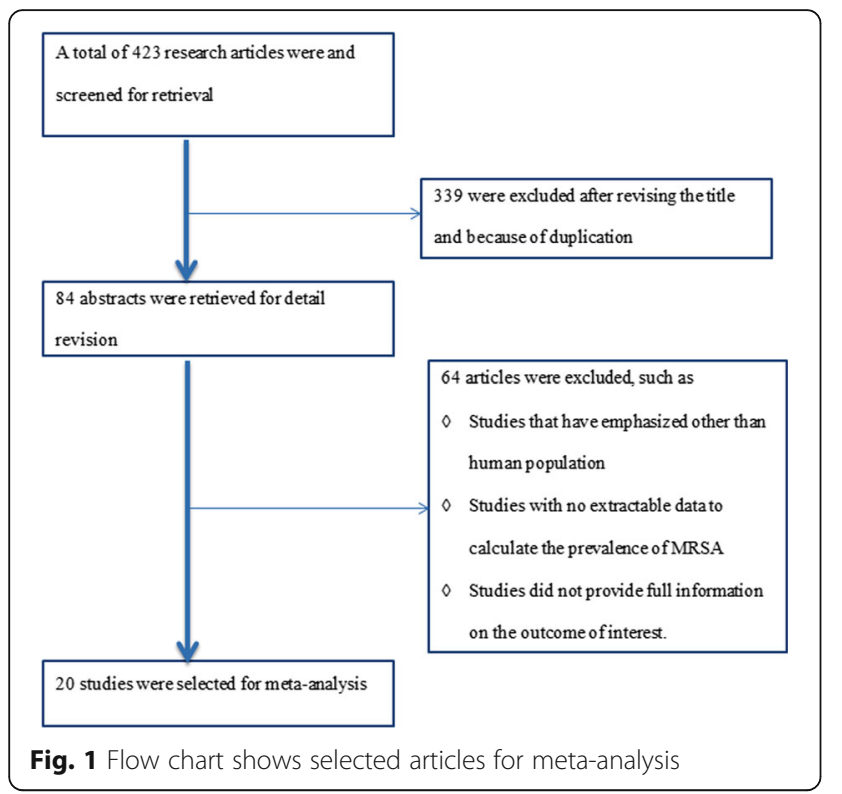

As presented in Forest plot (Fig. 2), the pooled prevalence of MRSA colonization was 32.5\% (95\% CI, 24.1 to 40.9\%; $P<0.001$ ). There was a high level of heterogeneity, random model methods $\left(\mathrm{I}^{2}=96 \%, P<0.001\right)$. Since, the included studies have been conducted in different setups, study periods, and study populations, which could have an effect on the heterogeneity of the included studies. Symmetry of funnel plot shows small study bias yielded insignificant effect.

Selected articles were published from 2007 to 2015 and year of study were ranged from 2004 to 2014 . Besides, all included publications were obtained from 4 regions and including the Federal capital city of Ethiopia, Addis Ababa, but no data was obtained from other regions (Afar, Benishangul-Gumuz, Gambela and Somali). Most of the studies indicated that various specimens had been utilized for screening MRSA, especially multisite swabbing was performed from different parts of the body, such as, skin, nasal, eye, ear, urethra, throat, vagina or genital area (Table 1). The lowest and highest proportions of MRSA were reported respectively, from Addis Ababa and Bahirdar cities [30, 33]. As shown from Fig. 3 the average prevalence of MRSA was also noted in different regions of Ethiopia, hence Southern Ethiopia region ranked first (40.4\%), followed by Oromia region (39.1\%), and Addis Ababa (31.6\%), whereas relatively low magnitude of MRSA were demonstrated from Tigray region $(20.3 \%)$.

Furthermore, of the selected articles, seven studies have extractable data on the antibiotic resistance profile of MRSA isolates [16, 18, 20, 21, 23, 26, 33]. The pooled resistance rates of MRSA for each tested antibiotics has been presented Table 2; and therefore, high resistant rates were observed to penicillin (99.1, 95\% CI: 98-100\%), ampicillin (98.1\%, 95\% CI: 95.7-100\%), erythromycin

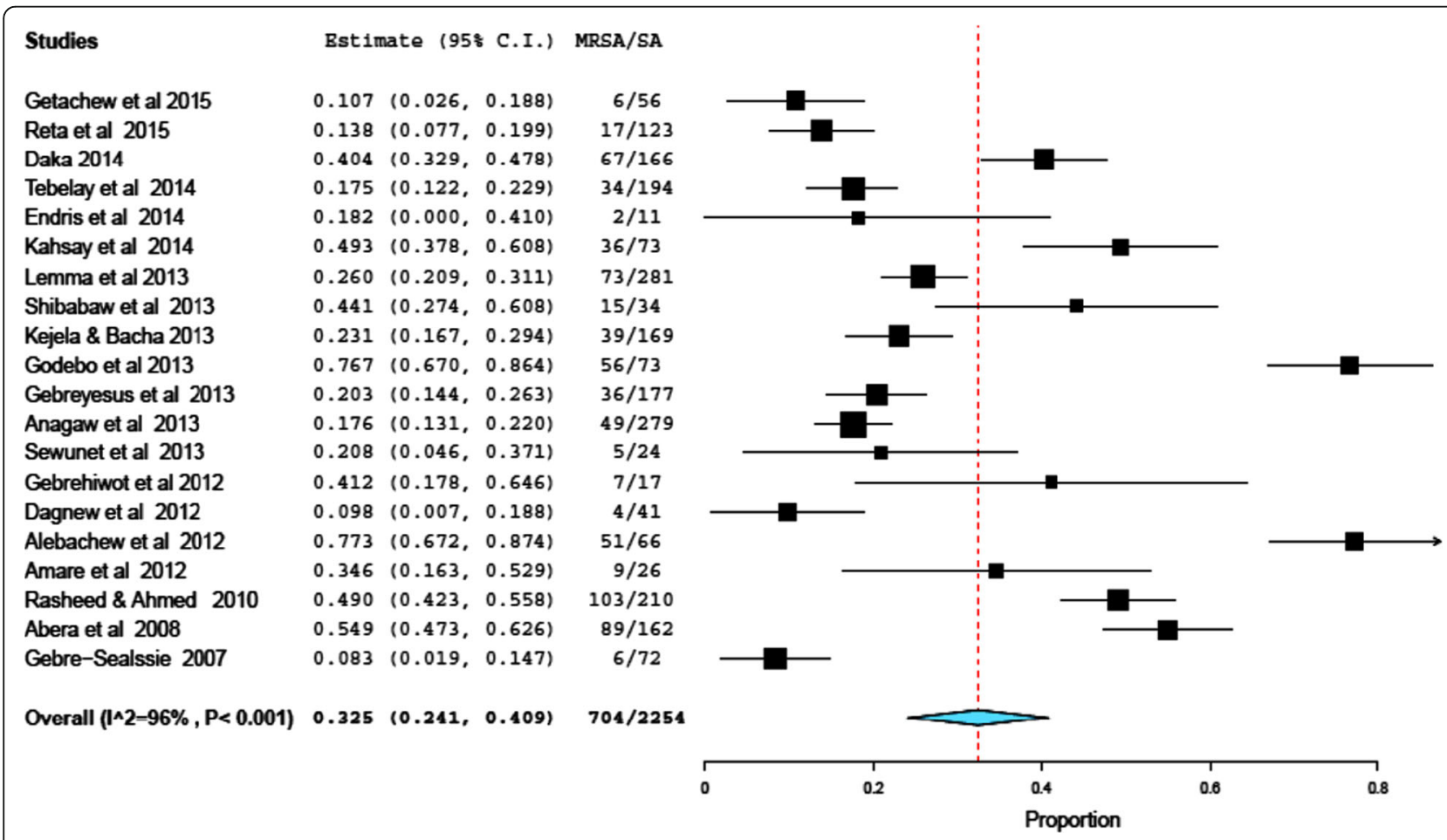

Fig. 2 Forest plot of the pooled prevalence of MRSA in 20 studies, Ethiopia, 2004-2015 
Table 1 Summary of 20 studies reporting the prevalence of MRSA in different parts of Ethiopia, 2004-2015

\begin{tabular}{|c|c|c|c|c|c|c|c|c|}
\hline Region & Study area & Study period & Study design & Study population & Culture specimens & $\begin{array}{l}\text { No of } S . \\
\text { aureus } \\
\text { isolates }\end{array}$ & $\begin{array}{l}\text { Percentage of } \\
\text { MRSA, N (\%) }\end{array}$ & References \\
\hline \multirow[t]{10}{*}{ Amhara } & $\begin{array}{l}\text { Bahirdar, Dessie } \\
\text { and Debre Tabor }\end{array}$ & $\begin{array}{l}\text { December } 2013 \text { to } \\
\text { April } 2014\end{array}$ & Cross-sectional study & $\begin{array}{l}\text { HIV infected pediatric } \\
\text { patients }\end{array}$ & $\begin{array}{l}\text { Skin swab, nasal swab, } \\
\text { and perineum swab }\end{array}$ & 281 & $73(26)$ & Lemma et al. 2015 [17] \\
\hline & Gondar & February to May 2012 & Cross-sectional study & VL patients & Blood & 11 & $2(18.2)$ & Endris et al. 2014 [15] \\
\hline & Gondar & July 2011 to June 2012 & Cross-sectional study & Neonates & Blood & 17 & $7(41.2)$ & Gebrehiwot et al. 2012 [24] \\
\hline & Gondar & January to June 2011 & Cross-sectional study & Food handlers & Nasal swab & 41 & $4(9.8)$ & Dagnew et al. 2012 [25] \\
\hline & Gondar & $\begin{array}{l}\text { September } 2009 \text { to } \\
\text { June } 2010\end{array}$ & Cross-sectional study & In and out patient & $\begin{array}{l}\text { Urine, eye discharge, genital } \\
\text { swab, body fluid, pus, wound } \\
\text { swab and discharge }\end{array}$ & 279 & $49(17.6)$ & Anagaw et al. 2013 [22] \\
\hline & Gondar & January to June 2010 & Cross-sectional study & $\begin{array}{l}\text { Patients with } \\
\text { post-operative } \\
\text { surgical site Infections }\end{array}$ & Pus swab & 26 & $9(34.6)$ & Amare et al. 2012 [27] \\
\hline & Bahirdar & April to June 2006 & Cross-sectional study & In and out patient & $\begin{array}{l}\text { surgical wound, ear } \\
\text { discharges, eye } \\
\text { discharges and } \\
\text { throat swabs }\end{array}$ & 162 & $89(54.9)$ & Abera et al. 2008 [29] \\
\hline & Debre Markos & March to June 2013 & Cross-sectional study & School children & Nasal swab & 123 & $17(13.8)$ & Reta et al. 2015 [12] \\
\hline & Debre Markos & December 2011 to March 2012 & Cross-sectional study & $\begin{array}{l}\text { Patients with surgical } \\
\text { site infection }\end{array}$ & Wound swab & 73 & $36(49.7)$ & Kahsay et al. 2014 [16] \\
\hline & Dessie & November 2010 to March 2011 & Cross-sectional study & Healthcare workers & Nasal swab & 34 & $15(44.1)$ & Shibabaw et al. 2013 [22] \\
\hline \multirow[t]{4}{*}{ Oromia } & Jimma & June to December 2011 & Cross-sectional study & In and out patient & Wound swab & 73 & $56(76.7)$ & Godebo et al. 2013 [20] \\
\hline & Jimma & $\begin{array}{l}\text { December } 2010 \text { to } \\
\text { June, } 2011\end{array}$ & Cross-sectional study & $\begin{array}{l}\text { Primary school children } \\
\text { and prisoners }\end{array}$ & Nasal swab & 169 & $39(23.1)$ & Kejela and Bacha, 2013 [19] \\
\hline & Jimma & January 2003 to July 2004 & Cross-sectional study & Out patients & $\begin{array}{l}\text { Ear discharges, throat and } \\
\text { wound swabs }\end{array}$ & 72 & $6(8.3)$ & Gebre-Sealsssie, 2007 [30] \\
\hline & $\begin{array}{l}\text { Harar and } \\
\text { Jimma }\end{array}$ & - & Cross-sectional study & - & $\begin{array}{l}\text { Blood, CSF, pus, sputum } \\
\text { and urine }\end{array}$ & 210 & $103(49)$ & $\begin{array}{l}\text { Rasheed and Ahmed, } \\
2010 \text { [28] }\end{array}$ \\
\hline \multirow[t]{3}{*}{$\begin{array}{l}\text { Central } \\
\text { Ethiopia }\end{array}$} & Addis Ababa & March to August 2015 & Cross-sectional study & $\begin{array}{l}\text { Post operative } \\
\text { patients }\end{array}$ & Wound swab & 56 & $6(10.7)$ & Getachew et al. 2015 [11] \\
\hline & Addis Ababa & $\begin{array}{l}\text { September } 2013 \text { to } \\
\text { April } 2014\end{array}$ & Cross-sectional study & In and out patient & $\begin{array}{l}\text { Nasal swab, wound swab, ear } \\
\text { discharge, blood, throat swab, } \\
\text { eye swab, vaginal discharge, } \\
\text { urethral discharge, urine, stool, } \\
\text { sputum, CSF and body fluids }\end{array}$ & 194 & $34 /(17.5)$ & Tebelay et al. 2014 [14] \\
\hline & Addis Ababa & March to May 2011 & Cross-sectional study & $\begin{array}{l}\text { In and out patient } \\
\text { (burn patients) }\end{array}$ & Wound swab & 66 & $51(77.3)$ & Alebachew et al. 2012 [26] \\
\hline
\end{tabular}


Table 1 Summary of 20 studies reporting the prevalence of MRSA in different parts of Ethiopia, 2004-2015 (Continued)

\begin{tabular}{|c|c|c|c|c|c|c|c|c|}
\hline & Addis Ababa & April to July 2010 & Cross-sectional study & $\begin{array}{l}\text { In and out patient } \\
\text { (burn patients) }\end{array}$ & Blood and wound swabs & 24 & $5(20.8)$ & Sewunet et al. 2013 [23] \\
\hline Tigray & Mekelle & $\begin{array}{l}\text { November } 2010 \text { to } \\
\text { January } 2011\end{array}$ & Cross-sectional study & Health care workers & $\begin{array}{l}\text { Nasal swab and material } \\
\text { from hand }\end{array}$ & 177 & $36(20.3)$ & Gebreyesus et al. 2013 [21] \\
\hline $\begin{array}{l}\text { Southern } \\
\text { Ethiopia }\end{array}$ & Hawassa & $\begin{array}{l}\text { August } 2013 \text { to } \\
\text { December } 2014\end{array}$ & Cross-sectional study & Health care workers & $\begin{array}{l}\text { Sample from hand and } \\
\text { mobile phones }\end{array}$ & 166 & $67(40.2)$ & Daka, 2014 [13] \\
\hline
\end{tabular}

Keys: CSF Cerebro-spinal fluid, HIV Human immuno-deficiency virus, VL Visceral leshimaniasis 


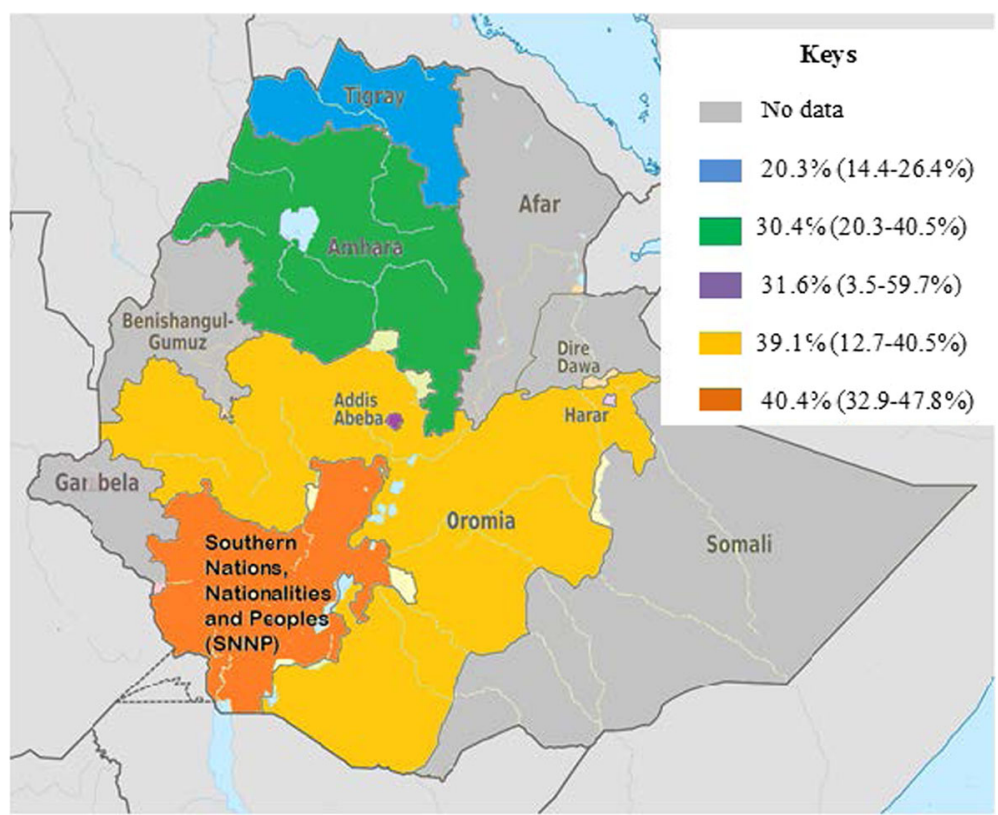

Fig. 3 Proportion of MRSA in different regions of Ethiopia, 2004-2015

(97.2\%, 95\% CI: $23.2-100 \%)$ and amoxicillin (97.1\%, 95\% CI: 92.7-100\%). In contrast, low level of vancomycin resistance has been calculated, 5.3\% (95\% CI: 0-10.6\%).

\section{Discussion}

Antibiotic resistance continues to be a global setback in the management of common bacterial infections diseases. Particularly, the problem of antibiotic resistance is highly pronounced in resource limited countries, including Ethiopia, where infectious diseases are rampant [3]. A first global report on the antimicrobial resistance claimed that MRSA is one of the most implicated multidrug resistant (MDR) strains, which has shown a high level of resistance against both beta lactam and non-beta lactam agents [35].

To date, the overall epidemiology and burden of MDR bacteria have not fully understood, especially in resource limited countries [3, 35]. To the best of our knowledge, it is the first a meta-analysis study conducted to determine pooled prevalence of MRSA in Ethiopia. According to this meta-analysis, the overall estimation of MRSA prevalence in Ethiopia was 32.5\% (95\% CI, 24.1 to $40.9 \%$; $P<0.001)$. This is comparable with meta-analysis studies conducted in similar settings [36-40]. However, this

Table 2 Pooled antibiotic resistance rates of MRSA strains; Ethiopia, 2006-2014

\begin{tabular}{|c|c|c|c|c|c|c|c|c|}
\hline \multirow[t]{2}{*}{ Antibiotics } & \multicolumn{7}{|c|}{ Antibiotic resistance rate reported by 7 studies } & \multirow{2}{*}{$\begin{array}{l}\text { Pooled resistance } \\
\text { rate, \% ( } 95 \% \text { Cl) }\end{array}$} \\
\hline & $\begin{array}{l}\text { Lemma et al. } \\
2015 \text { [17] }\end{array}$ & $\begin{array}{l}\text { Anagaw et al. } \\
2013 \text { [22] }\end{array}$ & $\begin{array}{l}\text { Abera et al. } \\
2008 \text { [29] }\end{array}$ & $\begin{array}{l}\text { Kahsay et al. } \\
2014 \text { [16] }\end{array}$ & $\begin{array}{l}\text { Reta et al. } \\
2015 \text { [12] }\end{array}$ & $\begin{array}{l}\text { Kejela \& Bacha, } \\
2013 \text { [19] }\end{array}$ & $\begin{array}{l}\text { Tebelay et al. } \\
2014 \text { [14] }\end{array}$ & \\
\hline Chloramphinicol & $4(5.5)$ & $22(44.9)$ & - & - & 0 & $23(59)$ & $16(47.1)$ & $30.8(30.3-63.8)$ \\
\hline Ceftriaxone & $15(20.5)$ & $2(4.1)$ & $85(95.5)$ & - & 0 & - & & $30.8(0-84.1)$ \\
\hline Ciprofloxacin & $17(23.3)$ & $2(4.1)$ & $67(75.3)$ & - & 0 & - & $28(82.4)$ & $37.3(5.9-68.7)$ \\
\hline Clindamycin & $6(8.2)$ & $1(2)$ & - & $22(61.1)$ & 0 & - & $18(52.9)$ & $23.1(7.5-38.8)$ \\
\hline Cotrimoxazole & $4(5.5)$ & $22(44.9)$ & - & $36(100)$ & $2(11.8)$ & $7(17.9)$ & $34(100)$ & $46.4(8.4-84.5)$ \\
\hline Erythromycin & $17(23.3)$ & $9(18.4)$ & $69(77.5)$ & $35(97.2)$ & 0 & $24(61.5)$ & $34(100)$ & $97.2(23.2-100)$ \\
\hline Tetracycline & $53(72.6)$ & $10(20.4)$ & $80(89.9)$ & $15(41.7)$ & - & 13 (33.3) & - & 51.9 (22.8-81) \\
\hline Pencillin G & - & 49 (100) & 89 (100) & $36(100)$ & $17(100)$ & $39(100)$ & $34(100)$ & 99.1 (98-100) \\
\hline Ampicillin & - & 46 (93.9) & - & 36 (100) & - & 39 (100) & - & $98.1(95.7-100)$ \\
\hline Amoxacillin & - & $46(93.9)$ & - & $36(100)$ & - & & - & $97.1(92.7-100)$ \\
\hline Vancomycin & - & 0 & 0 & - & - & $5(12.8)$ & $10(29.4)$ & $5.3(0-10.6)$ \\
\hline Gentamycin & - & - & $63(70.8)$ & $34(94.4)$ & 0 & $6(15.4)$ & $13(38.2)$ & $44.4(4.9-83.9)$ \\
\hline
\end{tabular}


finding is relatively higher than from reports indicated in high income countries [41-43]. It is well known that risk factors associated with MDR strains are comparatively higher in developing countries [3, 44].

Reasonably, there are several issues which can be either directly or indirectly related to the growing burden of MDR prevailing bacterial pathogens including MRSA. Even though, the development of resistance is a normal evolutionary process for microorganisms, but it is highly aggravated by continuous deployment of antimicrobial drugs in treating infections has led to the emergence of resistance among various strains of bacteria [45, 46]. It is claimed that more than $50 \%$ of drugs prescribed, sold or dispensed without following standard protocols, and the situation is more magnified in developing countries [47]. In low income countries in particular, antibiotic use is largely relied on clinical judgment without the benefit of specific diagnostic tools, which inevitably leads to rapid evolution of drug resistant strains, which is mainly due to irrational use of antibiotics [48, 49]. Likewise, according to Sosa et al. antibiotic use in most of developing countries is generally unregulated, which is a prime factor for the occurrence of resistant bacterial strains [3]. Therefore, it indicated that antibiotics are widely and inappropriately used in resource limited countries like Ethiopia, resulting to increased prevalence of drug resistant strains such as MRSA.

Additionally, regional prevalence of MRSA was also calculated, hence highest prevalence MRSA (40.4\%) was noted in Southern Ethiopia, which was almost two times higher than a result from Tigary region (20.3\%). Though, health workers were the study population in the studies of both regions, but as shown in Table 1, different types of samples were collected from participants (health workers), and therefore it would have an effect on the isolation rate of MRSA strains. Besides, the observed variation might be due to different study location, hospital setup, and study period.

Moreover, based on the data have been obtained from seven published articles; MRSA strains showed extremely high resistance rate to penicillin, ampicillin, erythromycin and amoxacillin, in contrast least resistance rate was observed to vancomycin. Similarly, a previous systematic review [50] has also documented that MRSA strains were found to be too highly resistant to the above mentioned antibiotics. It is understood that MRSA strains are able to express beta-lactam hydrolyzing enzymes so called betalactamases or capable of modifying penicillin binding proteins [51], hence it is not surprising, MRSA strains are capable of inactivating the beta-lactam agents such as penicillin, ampicillin, cephalosporins, and carbapenems. Even more, MRSA has a propensity to dismantle nonbetam lectam agents; this is largely due to co-existence of other resistance gene along with mecA or mecC gene
[52]. Most importantly, vancomycin is considerably the most effective and considered as the last resort treatment for resistant infections, especially of MRSA, despite the fact that the emergence of vancomycin resistant organisms has deprived the usefulness of this drug beyond any doubt [53]. Though low levels of vancomycin resistant indicated in this meta-analysis, but it indicates huge blow, especially for the future.

In general based on this finding, the burden of MRSA constitutes a major public health challenge in Ethiopia, thus health care facilities should adopt or establish guidelines to minimize cross-contamination by MRSA. Substantially, maintaining hand hygiene, applying infection prevention protocols, environmental sanitation, and wearing possible personal protective equipment are advocated for preventing infection. In addition to that promoting health education, professional educations as well as public awareness campaigns are evidently effective in the reduction of the unnecessary use of antibiotics, which in turn reduce selective pressure of mutant strains.

\section{Conclusion}

In this meta-analysis the pooled MRSA prevalence is considerably high. Aside from that more than 97\% of MRSA strain was found to be highly resistant to betalactam agents (penicillin, ampicillin and amoxacillin) and non-beta-lactam agents (erythromycin). In contrary, low level of resistance rate was observed to vancomycin. Thus, to combat the burden of MRSA in particular, the following concerns should be considered at the national level, such as adopting safety protocols and implementing proper antibiotic prescription policies.

\section{Abbreviations \\ $\mathrm{Cl}$ : Confidence interval; MDR: Multidrug resistant; MRSA: Methicillin resistant Staphylococcus aureus; SCCmec: Staphylococcal cassette chromosome mec}

\section{Acknowledgments \\ We would like to thank Mr. Mengistu Endires for facilitating training on meta-analysis and systematic review.}

\section{Availability of data and materials \\ No additional data are required; all information is clearly presented in the main manuscript.}

\section{Authors' contributions}

SE: Conception of research protocol, study design, literature review, data collection, data extraction, data analysis and interpretation, and drafting manuscript. FT, AA, FM, WB, and $\mathrm{KH}$ : literature review, data collection and extraction, and reviewing manuscript. All authors have read and approved the manuscript.

\section{Competing interests}

The authors declare that they have no competing interests.

Consent for publication

Not applicable. 


\section{Ethics approval and consent to participate}

We have meta-analyzed evidences obtained from studies that were particularly conducted in Ethiopia. Therefore, this study did not require approval from ethical committee.

\section{Author details}

'Department of Medical Microbiology, College of Medicine and Health Sciences, University of Gondar, P. O. Box: 196, Gondar, Ethiopia. ${ }^{2}$ Department of Anesthesia, College of Medicine and Health Sciences, Bahirdar University, Bahirdar, Ethiopia.

\section{Received: 31 March 2016 Accepted: 8 November 2016}

Published online: 21 November 2016

\section{References}

1. Freeman-Cook L, Freeman-Cook KD, Alcamo IE, Heymann DL. Staphylococcus aureus infections: Deadly diseases and epidemics. Infobase Publishing; 2006:26-29. Available online: http://www.infobasepublishing. com/Bookdetail.aspx?ISBN=1438101686\&eBooks=1.

2. Lowy FD. Antimicrobial resistance: the example of Staphylococcus aureus. J Clin Invest. 2003;111(9):1265-73.

3. Sosa AdJ, Amábile-Cuevas CF, Byarugaba DK, Hsueh P-R, Kariuki S, Okeke IN. Antimicrobial resistance in developing countries. Springer; 2010:3-15. Available online: http://emerald.tufts.edu/med/apua/about_us/publications 21_3125925763.pdf.

4. Hiramatsu K, Cui L, Kuroda M, Ito T. The emergence and evolution of methicillin-resistant Staphylococcus aureus. Trends Microbiol. 2001;9(10):486-93.

5. Cosgrove SE, Qi Y, Kaye KS, Harbarth S, Karchmer AW, Carmeli Y. The impact of methicillin resistance in Staphylococcus aureus bacteremia on patient outcomes: mortality, length of stay, and hospital charges. Infect Control Hosp Epidemiol. 2005;26(02):166-74.

6. Abdulgader SM, Shittu AO, Nicol MP, Kaba M. Molecular epidemiology of Methicillin-resistant Staphylococcus aureus in Africa: a systematic review. Front Microbiol. 2015;6(348):1-21.

7. Grema H, Geidam Y, Gadzama G, Ameh J, Suleiman A. Methicillin resistant Staphyloccus aureus (MRSA): a review. Adv Anim Vet Sci. 2015;3(2):79-98.

8. Bertrand X. Methicillin-resistant Staphylococcus aureus: an ever emerging threat. Therapy. 2010;7(2):169-78.

9. Gagliotti C, Balode A, Baquero F, Degener J, Grundmann H, Gür D, et al. Escherichia coli and Staphylococcus aureus: bad news and good news from the European Antimicrobial Resistance Surveillance Network (EARS-Net, formerly EARSS), 2002 to 2009. Euro Surveill. 2011;16(11):1-5.

10. DerSimonian R, Laird N. Meta-analysis in clinical trials. Control Clin Trials. 1986;7(3):177-88

11. Fazel S, Khosla V, Doll H, Geddes J. The prevalence of mental disorders among the homeless in western countries: systematic review and metaregression analysis. PLoS Med. 2008;5(12):e225

12. Barendregt JJ, Doi SA, Lee YY, Norman RE, Vos T. Meta-analysis of prevalence. J Epidemiol Community Health. 2013;67(11):974-97.

13. Rücker G, Schwarzer G, Carpenter JR, Schumacher M. Undue reliance on I(2) in assessing heterogeneity may mislead. BMC Med Res Methodol. 2008;8:79.

14. loannidis J. Interpretation of tests of heterogeneity and bias in meta-analysis. J Eval Clin Pract. 2008;14(5):951-7.

15. Getachew S. Multidrug resistant bacteria in postoperative wound infection at Tikur Anbessa specialized Hospital. Addis Ababa: AAU; 2015. Available online:http://etd.aau.edu.et/handle/123456789/8268.

16. Reta A, Gedefaw L, Sewunet T, Beyene G. Nasal Carriage, Risk Factors and Antimicrobial Susceptibility Pattern of Methicillin Resistant Staphylococcus aureus among School Children in Ethiopia. J Med Microb Diagn. 2015:4(1):1-6.

17. Daka D. Antibiotic-resistant Staphylococcus aureus isolated from mobile phone and hands of Health care workers in the Hawassa referral Hospital, South Ethiopia. J Microbiol Antimicrob. 2014;6(4):72-8.

18. Tebelay D. Prevalence and antimicrobial susceptibility pattern of methicillin resistant Staphylococcus aureus isolated from clinical samples at Yekatit 12 hospital Medical College. Addis Ababa: AAU; 2014. Available online: http://etd.aau.edu.et/handle/123456789/5640.

19. Endris M, Takele Y, Woldeyohannes D, Tiruneh M, Mohammed R, Moges F, et al. Bacterial sepsis in patients with visceral leishmaniasis in Northwest Ethiopia. Biomed Res Int. 2014;2014:1-7.

20. Kahsay A, Mihret A, Abebe T, Andualem T. Isolation and antimicrobial susceptibility pattern of Staphylococcus aureus in patients with surgical site infection at Debre Markos Referral Hospital, Amhara Region, Ethiopia. Arch Public Health. 2014:72(16):1-7.

21. Lemma MT, Zenebe Y, Tulu B, Mekonnen D, Mekonnen Z. Methicillin Resistant Staphylococcus aureus among HIV Infected Pediatric Patients in Northwest Ethiopia: Carriage Rates and Antibiotic Co-Resistance Profiles. PLoS One. 2015; 10(9):1-10.

22. Shibabaw A, Abebe T, Mihret A. Nasal carriage rate of methicillin resistant Staphylococcus aureus among Dessie Referral Hospital health care workers; Dessie, Northeast Ethiopia. Antimicrob Resist Infect Control. 2013;2(25):1-5.

23. Kejela T, Bacha K. Prevalence and antibiotic susceptibility pattern of methicillin-resistant Staphylococcus aureus (MRSA) among primary school children and prisoners in Jimma Town, Southwest Ethiopia. Ann Clin Microbiol Antimicrob. 2013;12(11):1-11.

24. Godebo G, Kibru G, Tassew H. Multidrug-resistant bacterial isolates in infected wounds at Jimma University Specialized Hospital, Ethiopia. Ann Clin Microbiol Antimicrob. 2013;12(17):1-7.

25. Gebreyesus A, Gebre-Selassie S, Mihert A. Nasal and hand carriage rate of methicillin resistant Staphylococcus aureus (MRSA) among health care workers in Mekelle Hospital, North Ethiopia. Ethiop Med J. 2013;51(1):41-7.

26. Anagaw B, Shiferaw $Y$, Anagaw B, Biadglegne F, Moges F, Kassu A, et al. Frequency of Methicillin-resistant Staphylococcus aureus isolates from Clinical Specimens in Gondar University Hospital, Northwest Ethiopia. Asian J Med Sci. 2013:5(3):59-64

27. Sewunet T, Demissie Y, Mihret A, Abebe T. Bacterial profile and antimicrobial susceptibility pattern of isolates among burn patients at Yekatit 12 Hospital Burn Center, Addis Ababa, Ethiopia. Ethiop J Health Sci. 2013;23(3):209-16.

28. Gebrehiwot A, Lakew W, Moges F, Anagaw B, Yismaw G, Unakal C. Bacterial profile and drug susceptibility pattern of neonatal sepsis in Gondar University Hospital, Gondar Northwest Ethiopia. Der Pharmacia Lettre. 2012;4(6):1811-6.

29. Dagnew M, Tiruneh M, Moges F, Tekeste Z. Survey of nasal carriage of Staphylococcus aureus and intestinal parasites among food handlers working at Gondar University, Northwest Ethiopia. BMC Public Health. 2012;12(1):1.

30. Alebachew T, Yismaw G, Derabe A, Sisay Z. Staphylococcus aureus burn wound infection among patients attending Yekatit 12 hospital burn unit, Addis Ababa, Ethiopia. Ethiop J Health Sci. 2012:22(3):209-13.

31. Amare B, Abdurrahman Z, Moges B, Ali J, Muluken L, Alemayehu M, et al. Postoperative surgical site bacterial infections and drug susceptibility patterns at Gondar University Teaching Hospital, Northwest Ethiopia. J Bacteriol Parasitol. 2011;2(8):1-6.

32. Rasheed M, Ahmed Z. Phenotypic methods of greater accuracy to detect the mecA gene product for the recognition of MRSA in resource constraint settings. Asian Pac J Trop Med. 2010;3(9):741-4.

33. Abera B, Alem A, Bezabih B. Methicillin-resistant strains of Staphylococcus aureus and coagulase-negative staphylococus from clinical isolates at Felege Hiwot Refferal Hospital, North West Ethiopia. Ethiop Med J. 2008; 46(2):149-53.

34. Gebre-Sealsssie S. Antimicrobial resistance patterns of clinical bacterial isolates in southwestern Ethiopia. Ethiop Med J. 2007:45(4):363-70.

35. World Health Organization. Antimicrobial resistance: global report on surveillance. World Health Organization; 2014. Availableonline: http:// www.who.int/drugresistance/documents/surveillancereport/en/

36. Kesah C, Redjeb SB, Odugbemi T, Boye C-B, Dosso M, Achola JN, et al. Prevalence of methicillin resistant Staphylococcus aureus in eight African hospitals and Malta. Clin Microbiol Infect. 2003:9(2):153-6.

37. Yousef SA, Mahmoud SY, Eihab MT. Prevalence of methicillin-resistant Staphylococcus aureus in Saudi Arabia: systemic review and meta-analysis. Afr J Clin Exp Microbiol. 2013;14(3):146-54.

38. Li S, Li J, Qiao Y, Ning X, Zeng T, Shen X. Prevalence and invasiveness of community-acquired methicillin-resistant Staphylococcus aureus: A metaanalysis. Indian J Pathol Microbiol. 2014;57(3):418-22.

39. Udobi C, Obajuluwa A, Onaolapo J. Prevalence and antibiotic resistance pattern of methicillin-resistant Staphylococcus aureus from an orthopaedic hospital in Nigeria. Biomed Res Int. 2013;2013:1-4.

40. Hajek JZLPP, Omrani NRA. MRSA infection and colonization rates in Africa and the Middle East; A Systematic review and meta-analysis. Presented at 16th International Congress on Infectious Diseases 2014. Available online: http://f1000research.com/posters/1095151.

41. Salgado CD, Farr BM, Calfee DP. Community-acquired methicillin-resistant Staphylococcus aureus: a meta-analysis of prevalence and risk factors. Clin Infect Dis. 2003;36(2):131-9. 
42. Zacharioudakis IM, Zervou FN, Ziakas PD, Mylonakis E. Meta-analysis of methicillin-resistant Staphylococcus aureus colonization and risk of infection in dialysis patients. J Am Soc Nephrol. 2014;25(9):2131-41.

43. Zervou FN, Zacharioudakis IM, Ziakas PD, Mylonakis E. MRSA colonization and risk of infection in the neonatal and pediatric ICU: a meta-analysis. Pediatrics. 2014;133(4):e1015-23.

44. Nelson N, Joshi M, Kirika R. Antimicrobial Resistance: The Need for Action in the East, Central and Southern Africa Region. Submitted to the US Agency for International Development by the Strengthening Pharmaceutical Systems (SPS) Program. Arlington, VA: Management Sciences for Health. 2009.Available online: http://apps.who.int/medicinedocs/documents/ s18415en/s18415en.pdf

45. Laxminarayan R, Duse A, Wattal C, Zaidi AK, Wertheim HF, Sumpradit N, et al. Antibiotic resistance- - the need for global solutions. Lancet Infect Dis. 2013;13(12):1057-98

46. O'Brien TF. Emergence, spread, and environmental effect of antimicrobial resistance: how use of an antimicrobial anywhere can increase resistance to any antimicrobial anywhere else. Clin Infect Dis. 2002;34(3):S78-84.

47. World Health Organization. Promoting rational use of medicines: core components. Geneva: WHO Press; 2002. Available at http://apps.who.int/ medicinedocs/pdf/h3011e/h3011e.pdf.

48. Shears P. Antibiotic resistance in the tropics. Epidemiology and surveillance of antimicrobial resistance in the tropics. Trans R Soc Trop Med Hyg. 2001; 95(2):127-30.

49. Vialle-Valentin C, Lecates R, Zhang F, Desta A, Ross-Degnan D. Predictors of antibiotic use in African communities: evidence from medicines household surveys in five countries. Trop Med Int Health. 2012;17(2):211-22.

50. Gebremariam TT, Zelelow YB. A systemic review of antimicrobial resistance pattern of methicillin-resistant Staphylococcus aureus. Saudi J Health Sci. 2014;3(2):71-4

51. Tenover FC. Mechanisms of antimicrobial resistance in bacteria. Am J Med. 2006;119(6):S3-S10.

52. Ardic N, Sareyyupoglu B, Ozyurt M, Haznedaroglu T, Ilga U. Investigation of aminoglycoside modifying enzyme genes in methicillin-resistant staphylococci. Microbiol Res. 2006;161(1):49-54.

53. Enright MC, Robinson DA, Randle G, Feil EJ, Grundmann H, Spratt BG. The evolutionary history of methicillin-resistant Staphylococcus aureus (MRSA). Proc Natl Acad Sci. 2002;99(11):7687-92.

\section{Submit your next manuscript to BioMed Central and we will help you at every step:}

- We accept pre-submission inquiries

- Our selector tool helps you to find the most relevant journal

- We provide round the clock customer support

- Convenient online submission

- Thorough peer review

- Inclusion in PubMed and all major indexing services

- Maximum visibility for your research

Submit your manuscript at www.biomedcentral.com/submit

) Biomed Central 